\title{
Defining the Russian Diasporic Home and Its Atmospheres: Theoretical Challenges and the Methodological Implications
}

\author{
Anna Pechurina \\ $\mathrm{PhD}$, Senior Lecturer in Sociology, Leeds Beckett University \\ Address: City Campus, Calverley Building, Room 914, Leeds, LS1 $3 \mathrm{HE}$ \\ E-mail: a.pechurina@leedsbeckett.ac.uk
}

\begin{abstract}
This article discusses the theoretical and methodological challenges in the qualitative research of Russian diasporic homes. Its key argument is that a sense of ethnic atmosphere and domestic aesthetics is co-created by the researcher and the participant through their shared perceptions of place in a process that has both advantages and limitations. Specifically, the article looks into the idea of "Russianness," which is defined as a collection of material and sensory elements that make one feel "at home." More importantly, this feeling of being "at (a Russian) home" and the atmospheres related to it can not only be experienced by those who live there, but also by its visitors who intuitively recognize the elements and objects of decor, and the domestic environment as being part of Russian culture. The interview situation helps to both reveal and to limit the meanings of the objects and of the stories which then constitute part of the existing atmosphere. Using examples from the previous study of Russian migrants' homes and complemented by the researcher's self-reflection, this article will explore the problematic nature of sensory dimension of home, and the challenges in approaching it both theoretically and methodologically. The article's enquiry is aligned with the argument of the importance of combining different ways of learning and knowing in sociological research (Smart, 2011), and aims to engage with the research context more critically and creatively.
\end{abstract}

Keywords: home, atmosphere, material culture, migration, diaspora, Russianness

\section{Introduction}

In this article, my experience of studying and visiting homes ${ }^{1}$ will be used to address several issues related to the conceptual and methodological understanding of domestic

(C) Pichurina A., 2016

(c) Centre for Fundamental Sociology, 2016

DOI: $10.17323 / 1728-192 X-2016-2-26-41$

1. The interview examples and research material are taken from a study of Russian migrants homes in the UK, conducted between 2006 and 2010. The main methods used were qualitative interviews at the participants' homes, and complemented by photographic images of material possessions or interior design. Additional ethnographic notes during the fieldwork were collected in the form of notes. The majority (23) of participants came to the UK during the period between 1990 and 2002, and thus belong to the post-Soviet wave of migration. There were also four participants who arrived between 1939 and 1954, and belonged to the first (after the Second World War) and the second migration waves (from the 1950s until the mid 1980s). Seven participants who arrived in the UK post-2002, which means that for the moment of the interview their stay in the UK was no longer than 5 years. The interviews took place during 2007 and 2008, were conducted in interviewees' homes, and lasted an average of sixty minutes with the majority of the interviews taking place in the North-West of England. For a more detailed account of the study methodology and results, please see Pechurina (2015). 
atmospheres where the social and personal worlds of researcher and participant come together within a single space. There has been a growing body of literature on home ethnography, including studies of homes and personal lives that highlight the importance of intangible and sensory dimensions of home, its material culture, and belonging (Hurdley, 2013; Miller, 2010; Pahl, 2012; Pink, 2004, 2006, 2012; Rose, 2012; Tolia-Kelly, 2010; Woodward, 2015). While my research is certainly placed within this framework, I aim to reflect upon how the intangible dimension of domestic space, which I refer to as "home" atmosphere, is connected to the culture and the identity of all of the research participants. Specifically, I look into and critically evaluate the idea of "home" atmospheres, which emerged as one of the defining characteristics of the Russian "Home from Home" and defined as a collection of elements, both material and sensory, that made one feel "at home." In the words of my research participants, one can speak about the presence of a "Russian spirit" or "Russian flavor" within the house that is linked to the way people defined and perceived their home. More importantly, this feeling of being "at (a Russian) home," which is also referred as Russianness, can be experienced not only by those who live there, but also by their visitors, who intuitively recognize elements of decor, objects, and the domestic environment as being part of Russian culture.

The method of home-based interviews used in my previous research of home cultures meant that I sometimes get to share my and my participants' understandings and meanings we attach to domestic artefacts, and to compare my sense of home with theirs. Invariably, listening, understanding, and interpreting the participants' explanations of domestic materiality is a core element of the ethnography of home. Through this process, one can reveal codes and practices, activities, and objects that can be defined as specific to a certain culture, in this instance, that of Russia. These often include specific and distinct ways of consuming food, looking after the house, or celebrating important national dates. But what contribution does the researcher make in creating and interpreting, and, consequently, defining and situating these meanings? Can the home's intangible and sensuous aspects be shared by the researcher and the participant alike? How does this enable or hinder definitions of the atmospheres of different cultures within the home in specific terms, in this case, those pertaining to Russian atmospheres? And, finally, how far does the very experience of being in the place determine the description of ethnic domesticity and the sensory response to it?

In the remainder of this paper, I will discuss several theoretical and methodological challenges that arise in the process of researching the home by focusing upon various interactional relationships that emerge between the researcher, the participants, and the materiality of the domestic space. The purpose is to further explore the dialectics of knowledge production in the home-based interview situation by considering the roles and contributions of both the researcher and the participants in the process of attempting to conceptualize otherwise-intangible elements and dimensions of space, such as "home atmosphere" and "Russianness." I shall start with an overview of the concepts of the "diasporic home" and the "diasporic object," outlining their problematic natures and the complex connections to culture, and the sense of place and belonging. In the second 
part of the article, I will present several reflective examples from my research practice that indicates the problematic and complex nature of a home atmosphere and its related "Russianness."

\section{The Study of Migrants and Diaspora}

The analysis in this article is placed within the wider framework of the study of migrant and diasporic cultures which examines how the experience of moving to a new country affects the strategies of home-making, culture-building, and identity re-construction. Theoretically, I draw on Anderson's concept of imagined communities (Anderson, 1983). I have linked these strategies to the material culture, and focus on the exploration of the relationships between cultural identity, and the choice of material objects that convey meaning throughout the migrational journey. This means that identity is socially constructed and manifested through everyday activities performed within and around the domestic space. Material possessions function as tangible mediators of intangible ideas, experiences, senses, and cultures.

It should be noted that migration is approached and understood through a narrative of movement that is not limited to crossing borders or spatial movement in general. Regardless of their place of residence, people (and especially migrants) go through various stages in life affecting their notion of "home," as well as the number and type of material possessions they own, which reflects their current sense of self or personal construction of meaning. Furthermore, I attempt to look at the experience of movement not only in terms of displacement and deterritorialization, but also as a way of getting to new destinations, including both spatial destinations and/or more metaphorical destinations representative of one's existential awareness. Any kind of movement is meaningful as long as it shapes an experiential reality. This includes visits from friends and relatives that intrude into the home atmosphere and fill it with reminders of "home;" revisiting previous homes; tourism that sparks memories; movements within the country of settlement, and the symbolic repositioning of people and objects in the process of re-identification. These movements are intricately involved in the process of the making, unmaking, and remaking of cultures and identities in diasporic contexts.

Exercising reflexivity and considering my own experience of movement and changing forms of spatial awareness-including the role and representation of objects in the making of identity - can provide an insight into the processes which are at play for the study's participants when they construct meaning in the diaspora. If we imagine a parallel universe in which, alongside the study's participants, we have been undergoing a journey of migration that has transformed our perception of "home" and our own identity narrative and modified our relationships with our home country and sense of home, then we can appreciate the transformations at play, and the role of spatial and symbolic movements in the process. For this reason, I am always aware of and take into account my own personal memories that form a part of the collective knowledge of domestic culture and the Russianness informing the analysis that follows. 


\section{Researching Homes and Objects}

In my research, "home" is perceived as a complex and multidimensional concept. The meanings of its tangible and intangible components, and the relationships between these components are my primary focus. In this approach, I loosely distinguish between three areas of enquiry: the "physical" home, which refers to tangible components, including the building and its objects; the "symbolic" or imagined home, which refers to the idea of home, or of specific symbolisms around it; and the "practiced" home, which refers to the practices of home-making and relationships that maintain a sense of home within a physical space (Blunt, 2005; Mason, 1989). In relation to the non-tangible aspects of domesticity comes the understanding of "home" as a "sensory totality" (Petridou 2001), where the main emphasis is placed on the sensory elements of home that comprise it, including smells, sounds, and the visual. The important point here is that the areas outlined are not distinct in practice, but rather are in constant interplay. This also means that each field entails a whole range of thematic references. For instance, the "symbolic home" can be conceptualized as "imagined," where "home" represents a past experience (a home left behind), or a destination (an ideal "home" yet to be found).

The outlined dimensions of homes and material culture have been widely explored in recent studies of migrant communities and cultures (Mehta, Belk, 1991; Miller, 2008; Savas, 2014; Svasek, 2012). Migrant communities present interesting cases for studying domestic cultures, as their homes "move" with them, both geographically and symbolically. Integral to the process of movement is the task of "selecting" the material objects they would take, leave behind, or gradually acquire in the new place. The practical tasks and experiences that migrants encounter on arrival are also influenced by other important socio-cultural factors, including cultural values, stereotypes and expectations of both migrants and local communities, economic conditions, and the scale of globalization within the area which either enables or restricts access to certain products and items. For instance, it is well known that London's highly globalized economy offers a wider range of ethnic products than other British localities where people may not have access to Russian items. At the same time, the rise of online shopping positively influences migrants' consumption of their "ethnic"/national items, including food, consumables, and other products. Also, political conflicts and economical factors can encourage "patriotic" consumption or non-consumption of items (Gurova, forthcoming). For instance, the economic sanctions against Russia affected which products migrants would buy to bring back to Russia. The symbolic power of things can work both ways: while some people purchase objects as reminders of places, others avoid them for the same reason. This is because things can remind migrants of homes past too intensely. Overall, external factors and the level of access to resources due to combinations of forms of capital are important to acknowledge when one studies migrant homes.

It is important to reiterate that regardless of the number of possessions one may have, the very idea of "home" remains a strong reference point for diasporic and migrant communities (Rapport, Dawson, 1998; Sigona et al., 2015), often functioning as a site where 
identities, cultures, relationships, memories, and ideologies are continuously configured and manifested. By studying "home" as a multi-dimensional concept and not focusing on the material and consumer characteristics of migrants' domesticity, sociologists have been able to learn not only about migrants' material cultures, but also about their ways and processes of maintaining cultural identity and a sense of belonging. This means that material objects are studied not only for their functional qualities, but also in terms of learning how these objects are thought of by their owners in ways that include the contextually-specific meanings attached to these objects. This is often achieved by identifying specific practices that help migrants to feel connected to their community, practices through which they recreate the feeling of a "home from home," or of "a place other than one's own home where one can be at ease" (Hanks, 1979: 701). The argument that the study of "home" should go beyond simplistic descriptions of possessions and instead focus on the interpretations of their significance and the ways in which objects are used within the domestic context is important for this article, especially when it comes to homes that contain similar ethnic objects. For instance, one person's home may be full of cultural artefacts but another's empty; this alone does not make one home more Russian or more "home-ly" than the other (where "home-ly" confers ethnic identification). However, if we add elements of everyday activities to the study, such as cooking or the performance of other family rituals that make use of domestic objects, including birthday celebrations, cleaning the home, spending time with friends and relatives, relationships with the wider community as well as the level of participation in social networks, then it would be possible to arrive at a better understanding of a "feeling at home." Furthermore, apart from the use of objects in the context of social engagement, it is also productive to study objects and their individual or private uses, such as mnemonic objects (Marcoux, 2001), personal memorabilia or so-called "dormant things" (Woodward, 2015) that are stored for years in the closet, but act as important constituents of the "feeling of home." This point will be developed later in the article in relation to the "home" atmosphere.

There is a further typology of material objects that emerges when we study migrant homes and communities more closely. Thus, one can identify a group of objects that, along with personal components of identity, acquire additional "cultural" or "diasporic" meanings. In this sense, such objects act as visible references to the migrants' relationships and attachments to their "native" culture. In other words, "diasporic objects" can be defined as items that are related to stereotypical elements of culture and its rituals, including national or religious symbols, food, and souvenirs. In some instances, these are the same items that many tourists bring back with them from their trips abroad. Alternatively, items related to specific cultural or historical contexts, or to the traditions of a particular region or town, constitute another class of objects that acquires significance and meaning in and for the diaspora. Due to their commonness and to their widespread availability, these items are often among the popular objects brought home, or presented as gifts with the intention of reminding oneself and others of the native culture, while simultaneously affirming the heritage from which they derive. When it comes to the Russian culture, some of the most common examples of diasporic objects are items that 
carry national symbolisms (posters, calendars, or badges), traditional folk items (such as matrioshka dolls, wooden crockery, or traditional porcelain), and familiar foods (dairy products such as smetana or kefir).

At the same time, it should be noted that the identification of diasporic objects can be both productive and problematic when it comes to the study of deterritorialized migrant communities. First, we have to acknowledge other important categories of objects that can also be used by migrants, but which do not look stereotypically ethnic. For instance, an object identified as Russian is not necessarily diasporic (it is from Russia). A common Russian souvenir can be an important referent to personal biography or family history as well as to Russian culture (Pechurina, 2011: 104-107). Additionally, some things can be used and kept not only as a way to signify belonging to an imagined community, but also to act as compensation for social exclusion (Ibid.: 104-105). Furthermore, in regards to Russia, one should be aware of the controversy of Soviet/post-Soviet/Russian cultural fields as a result of which the meaning of many symbolic objects have become contested in different contexts. For instance, Soviet symbols can be presented both as kitsch and as a national symbol, which is also an indicator of the socio-cultural background of their owner ${ }^{2}$. A collection of plates from a national producer can be linked to a love of art and aesthetics. "Traditional" food choices can be justified by the interest in the history of one's country rather than familiarity of taste. The meanings of souvenirs can be reinterpreted and used ironically and playfully (as in "kitsch camp" meanings), as often happens with the symbols of the Soviet era. In other words, such dimensions as age, gender, or class and related categories of taste play their part in providing the further contextualization of the meaning of "diasporic" objects.

All in all, the practice of bringing and using diasporic objects both within the domestic space and in community-building activities surely deserves further investigation. Such practices as transnational shopping, gift-giving, food-sharing, and the reproduction of quasi-cultural activities indicate that diasporic objects play an active part in linking communities and cultures. Furthermore, diasporic objects are often highly visible within the domestic decor and are one of the first things to be noticed by a visitor and, for this reason alone, add a further dimension to the already polysemic notion of home. At the same time, despite their visibility, these objects' functional meaning is often blurred, and, in many cases, appear merely as a point of reference rather than as a profound identity statement. Finally, the distinctions of taste and class differences affect the construction of the meaning of diasporic objects, and by this, reveal further configurations of how the sense of belonging and the sense of identity can be mutually (i.e., both by the dweller and their visitor) constructed and maintained.

The main implication for a researcher of cultural identity and home-making is that diasporic objects visually produce the effect of native homes, which can both guide the researcher towards significant meanings and insights and mislead them. In my experience as researcher, I have regularly come across homes that contained a visible number

2. Further discussion on post-Soviet kitsch and its symbolism is outlined in Sabonis-Chafee (1999). 
of objects that looked Russian or Soviet, and were identified by their owners as such ${ }^{3}$. However, it was only after talking to the inhabitants that I was able to understand the functionality and significance of those objects to the persons' identities. People were able to distinguish between those items they did not much care about and were there only to fill the space, and those "subjective" items used for the specific purpose of creating a sense of home. In other words, the way in which inhabitants see and present their home is not always evident or self-explanatory to a visitor. Clichéd or hackneyed cultural symbols can be unimportant to the owners, or they may be enriched with meaning. The same logic applies to the study of other intangible dimensions of "home," including the feeling of being at "home," and of a "home" atmosphere.

\section{The Sociological Study of Atmospheres}

The concept of atmosphere, although not entirely new to social sciences, has begun to receive more scholarly attention in recent years, especially in connection to the growing interest in the sensory dimensions of place, belonging, and cultural identity. In the studies related to homemaking practices, "atmosphere" is referred to as an intangible characteristic of place that produces a particular sensory or emotional response ("pleasant," "warm," "cozy," "cold," and so forth), or a particular type of sociality (such as "friendship," "family," "kinship," or "intimacy"). At the same time, atmosphere can be linked to the qualities of the material objects located in the home; for instance, certain objects can have an effect on an individual's senses and emotions. Related to this argument, the theoretical conceptualization of atmosphere resides in Bohme's theory of aesthetics (Bohme 1993). According to Bohme, objects manifest their presence to the viewer through their physical qualities radiating outwards to the environment (Bohme, 1993: 121). Bohme defines these qualities as the "ecstasies of the thing," and links them to the visible articulations of the presence of objects in their environment, such as color, smell, shape, or texture, among other qualities. Atmospheres are revealed through such "ecstasies," that is, through the continuous (re)configurations of relationships between human subjects, material objects, and places. Correspondingly, viewers or visitors attune themselves to the space, recognize the ecstasies and, in doing so, participate in the co-production of atmosphere. Some aspects of this theory can be traced to Benjamin's concept of "aura," which he developed in relation to works of art (Benjamin, 2008). The aura is defined as the sensory effect that art objects have on the viewer, the "something" that separates those objects in time and space and makes them unique. In other words, when a viewer encounters a work of art, s/he experiences its aura, which is only possible when a work of art is unique and authentic. Although it is not uncommon to see unique works of art in people's homes, the domestic context is different to the museum or gallery environment that Benjamin mainly referred to in many ways. At the same time, following the discussion in the previous section, it can be argued that even a mass-produced item can have

3. The examples include Russian or Soviet flags, Russian folk souvenirs, Orthodox icons, posters and calendars, china cabinets, objects from hometowns, photographs, books, or food, among others. 
unique qualities due to a special significance for the owner. In the same way that art objects to which our access is limited are admired at a distance (Benjamin, 2008: 219-220), the cherished objects of the past are remembered and perceived as more special. A good illustration of this can be seen in the migrants' desires to bring "familiar" objects from their native countries. The very experience of migration means that one has to go back from the here-and-now to the there-and-then to get the object, and, by doing so, helps generate the object's aura. In this context, experiences and memories of the past linked to an object make it more special. When placed in the house, these special objects can affect the sensory perception of place.

At the same time, although in a slightly different way, the continuous practices of domesticity, or of the dwelling itself, enables greater integration with newly acquired objects. Thus, the attachment and emotional response can be established in relation to the relatively new objects as they gradually become integrated into the domestic setting and for its inhabitants and visitors. In this context, Chevalier's study of suburban homes may be effective at elaborating this connection. Chevalier (1999) explores those ways and processes through which a living space can be transformed into the meaningful space of one's "home." In doing this, she focuses on the material culture of the residents of several apartments in the Parisian suburbs. As she notes, the residents develop particular types of relationship with their objects, which she defines as "affinities," that transform the place and make it more meaningful (Chevalier, 1999: 88). Interestingly, once the objects are invested with emotions, even the most common mass-produced items are able to affect perceptions of "home" among their owners. It can be argued that these "affinities" add an extra layer to the residents' identities and to the ways in which they can be expressed. These objects' extra layers of "affinities" are gradually built up over time and by the number of personal references they acquire, such as their connection to the places that one has visited, and/or to significant people and memories. In other words, the objects start to "belong" to a place.

In relation to the concepts outlined above, it is important to mention the empirical studies of "home" atmosphere that focused on exploring how different social, cultural, spatial and sensory dimensions of "home" become (inter)connected in a meaningful way. In his study of "home" atmosphere through systematic qualitative interviews, Pennartz (1986) focused on investigating the types of experience of atmosphere at homes in different contexts, taking into account the relationships between the physical/spatial and social environments. In trying to overcome the conceptual complexity of defining atmosphere, Pennartz operationalized it through the term "pleasantness" (Pennartz, 1986: 138). Thus, to Pennartz, atmosphere is a characteristic of place that derives from the different combinations of spatial and social experiences and situations at home that one defines as "pleasant." Pennartz outlined several themes related to how the non-spatial and spatial characteristics of place indicate the presence of atmosphere at home. One of the conclusions was that the relationships between place, objects, and subjects are fluid and interactive. Furthermore, the spatial or material characteristics of place both produce and are produced by the individuals who inhabit it; "atmosphere manifests itself as a double 
sided process: the atmosphere of a room works on an individual, and conversely an individual projects his or her specific mood on the room" (Ibid.: 95).

Olesen's (2010) research develops some of these arguments further in relation to socalled "ethnic objects," that is, hand-made craft objects or furnishings of non-Western origin. Specifically, she questions the popularity of hand-made cloth of Malian origin with a distinctive traditional African pattern which has become popular among middleclass American consumers as home décor and/or furnishings. As Olesen argues, ethnic objects are an interesting case because of their capacity to alter the sensuous perception of "home" for their owners. Thus, items bought with the intention of decorating a home and of bringing some "ethnic" flavor to it appeared as a way of linking "space, material culture and social experience" (Olesen, 2010: 30). Correspondingly, Olesen's participants developed a defined sense of place, or atmosphere, created through the physical qualities such as the color or the pattern of their ethnic objects. In discussing the descriptions of "home" with her informants, Olesen also showed that their understandings of atmosphere were linked to other important cultural distinctions, such as the domestic/public sphere, kinship, sociality, order, and taste, among other things (Ibid.: 38). Essentially, the function of ethnic objects was to embody or "radiate those qualities" (Bohme, 1993), and to display them or project them outwards.

To summarize, it can be argued that the presence of an ethnic atmosphere is linked both to the place and to the objects located within it. Both the participants and the researcher perceive and respond to a place, thus constructing and co-producing its atmosphere. The ability to perceive the place in a specific way (as more-or-less Russian, for instance) depends on factors deeply ingrained into the social and cultural contexts and identity-definers of the interview participants. As a result, the focus should be shifted from identifying the descriptive elements of domesticity and their meanings to the analysis and unpacking of how and in what way sensory responses to place or its atmosphere is constructed by the interview participants, and how attention to certain objects is performed, communicated, and further described by the researcher. ${ }^{4}$

\section{Atmospheres of "Russianness"}

In my previous work on Russian migrants' homes (Pechurina, 2015), the notion of atmosphere emerged as a combination of the feeling of being at home and a linked sense of "Russianness." While the latter referred to the sensuous perception of home as "Russian," which might or might not be determined by the presence of diasporic objects, the former related to a more generic experience of place as "a lived home," or "dwelling" (Heidegger, 1993). The combination of the two produced the effect of an atmosphere of "Russian-

4. Similar argument can be found in Filippov's (2008) account of atmosphere. He identifies several elements within the process of manifestation of a sense of place, involving the sensuous anticipation of an observer, a shared sense of place during the observation experience, and the unexpected effects of the environment that disrupt the observer's expectations (Filippov, 2008: 255-258). This approach is relevant as it emphasizes the changeable nature of a sense of atmosphere and enables its different interpretations by different actors. 
ness," or the intangible dimension of a Russian diasporic home that both reveals and constitutes the cultural identity of the inhabitants. In other words, my argument is that an atmosphere of "Russianness" at home is linked to migrants' cultural identities that are manifested through both the material and sensory environment of the domestic space.

Although the study focused on exploring both tangible and intangible dimensions of diasporic homes from the perspective of the research participants, it is important that the role and impact of the researcher (a home visitor) in producing and experiencing the atmospheres of "Russianness" is acknowledged. As was established in the previous sections, atmosphere has a practiced/dynamic nature, which means that it is continuously produced and reproduced. Beyond this, the interview situation creates conditions in which the atmosphere could be co-produced, or shared by the participant and the researcher alike. In the following paragraphs, I will further discuss the connection between the sensory response to place and the objects and atmosphere of a Russian home. I will also reflect upon what the act of researching domestic spaces brings to the interview encounter, and the researcher's ability to sense and interpret the atmospheric dimension of a place as Russian or not.

My first example continues the argument of the importance of an emotional investment in the objects and place for the creation of a home atmosphere. Thus, in conducting home-based interviews for my research on Russianness and domesticity, I noticed that participants referred to their senses and emotions to describe and explain their possessions and homes. The situation of investing home possessions with emotions and feelings has been described by other researchers of "home," including Pink's notion of the "sensory home" (2009), or Marcoux with that of "mnemonic objects" (2001), among others. However, my argument here is that the presence of objects that stimulates a strong emotional response from their owners also reveals and simulates ethnic atmospheres. Thus, in regard to communities "on the move," one can see how objects that are linked to past memories and experiences, or that remind one of a certain historical or cultural context could, at least potentially, have a stronger effect or else be more visible in the house. To illustrate this point, I will refer to my own personal experience of visiting my grandmother's home in a small village in Russia's Altai region for the first time in ten years. I consider this experience relevant for the purposes of this article for several reasons. The home I stayed at and experienced as a guest represented a "home in movement," or in flux. The objects and their location reflected the relationships between different contexts and family members. Although the house and many of the objects were familiar to me, I experienced it as a guest due to its natural transformation as a result of transformed family ties. Some of the items had belonged to my parents, while others I remembered from my childhood. The layout of the rooms had changed so that the house looked only somewhat familiar. In this sense, the objects had migrated, both metaphorically and literally. I could see that the small sofa I slept on as a child for at least ten years had found its way into the handmade village bathhouse to serve as a futon. The lights from one of the homes I had lived in with my parents had been moved to my grandmother's kitchen. There was a familiar kitchen set among the furniture which I remember my parents buy- 
ing and, of course, the old TV set was the second color TV owned by the family. In other words, the objects and their meanings were imprinted on my personal biography and inscribed into my understanding of my self. When I saw the objects, I recognized different facts from my and my family's biography, moments in the history of the country, and of the area in which my grandmother lived. The bonds, or "affinities" (Chevalier, 1999), were re-established with the items and revealed themselves through my memories. The very same affinities would enable me to recognize similar objects within private displays at other people's homes, or within various public displays. For me, the coffee cups with classical motifs or particular polka-dot tea bowls would stand out as "Russian" in a shop, restaurant, museum, or somebody's home, not least because of my own experience of owning or using similar objects in the past.

To continue the discussion, it is important to acknowledge that no analysis can fail to take class into account. Therefore, class and class-related notions of taste have been integrated into my research. As the auto-ethnographic example above shows, the material aspects of Russianness reveal not only individual, but also social and cultural dimensions as to what and how certain objects were employed, and the relation of these practices to the status of the owner. The very access to the physical space of home (the ability to rent or own), the legality of migrant status, and the occupation of home-dwellers shaped their potential "expertise" in how to use cultural codes and symbols of Russianness. In the same way, my ability to judge whether I enjoyed the materiality of a space or recognized specific practices as Russian revealed my own constructions of "nativeness" and "otherness." As a result, I had to continuously reflect on my positioning within the group, and how this reflecting affected the collected data (what was being shown to me and what was being seen by me?) (Author, 2014). As a Soviet/Russian-born researcher, I shared a number of cultural codes with my participants which I believe both helped and hindered me in recognizing certain characteristics of home-making strategies. For instance, some symbolic cultural references were more recognizable to me, such as souvenirs from the Soviet era, or crafts from a particular town, or music, literature, art, or other décor that was on display, as well as intangible dimensions such as smells, tastes, and "things that look Russian." This diary note from one of my research visits illustrates this process: "I still remember how strong my impression was ... When I first visited the house, I could not believe that we were in England; even the wallpaper looked Russian to me, although Olga said that she had bought it in the UK."

Clearly, my perception of Russianness was somewhat predefined and influenced by my social background and class, and by the sense and anticipation of a discovery common to all researchers. The permission to visit the home and share it with me at least implied established mutual trust and recognition. As was shown above, my own personal biography formed my preferences and notions of "special" and/or "Russian" objects. Some of them were simply more familiar to me than others. However, in the same way, participants expressed a variety of presumptions about Russianness as well. To some, it meant the presence of particular folk items in the house ("I don't have any matriosh$\left.k a s^{\prime \prime}\right)$, to others, it was the presence of art objects of Russian origin, but there were those 
who did not link it to a material culture at all, but to the social experiences of "home" (gatherings with friends and family, celebrating Russian holidays, etc.). As a result, some home visits presented me with objects and practices that I did not anticipate, while others complemented existing descriptions. In this latter situation, a deeper understanding of atmosphere was not specifically related to how well aligned my and my participants' perceptions of home were, but rather to how well I was able to recognize different types of relationship that each subject develops with and for that place. Is having a Russian samovar an expected diasporic practice? Should there be Russian products in the fridge? Should I expect to be offered to wear slippers at home? Should we conduct the interview in the kitchen or in the living room? Should the home be warm? Will there be many books in Russian on display?

I found a similar argument in Filippov's Sociology of Space (2008), where he states that it is only normal what an observer considers as familiar and close may or may not be a view shared by the participant. In Filippov's words, "my atmosphere and his/her atmosphere can or cannot be the same" (Filippov, 2008: 208). In other words, what I think is warm, cozy, and welcoming will not necessarily be considered so by someone else, but by comparing our attitudes and sense of place, one can enrich the sociological understanding of place and space. Hence, any attitude and relationship with place that is relevant to a particular research work is valid and important, and thus should be taken into account (Ibid.: 255).

Apart from attempting to grasp the "home" atmosphere empirically, the examples presented also highlight another very important issue related to the construction and presentation of taste. If atmosphere is linked to objects and to the ways these objects are used by their owners (i.e., home-making in a broad sense), it means that it also reveals distinctions in the perceptions and reassurances as to who and what people are or would like to be, and who or what people are not or would not like to be. Olesen shows it very well by emphasizing how normative constructions of domesticity among middle-class white American women informed their choices of ethnic objects, thus both reflecting and constructing the notions of Otherness and class-related taste (Olesen, 2010: 29). Another issue that logically follows is that the role of the researcher as observer and interpreter of domestic qualities is equally important as to how the interpretation of domestic atmosphere in the research situation contributes to the further construction of normative taste and "otherness." The relational and constructed nature of the concept of "home" means that perceptions of place can vary for different users of that place, and are certainly informed by other characteristics such as class, gender, and age that may or may not match in a particular interview situation. In this sense, the researcher anticipates and constructs the "otherness" of place in the same way as the participants try to present themselves and their homes to the researcher. Hence, the differences in judgements and responses to a place do not mean that one is more correct than the other, but rather that our social determinants come into play. Defining "home" as a fluid and changeable concept rejects the stability of the definition and, in some way, makes the home disappear (as it is constantly changing). However, this also means that we can shift the focus to practiced dimensions 
and sensory/atmospheric characteristics, and by this, achieve a more subtle and less essentialist understanding of how people perceive and use their place of living.

\section{Conclusion}

In this article, I discuss how the process of researching ethnic home cultures can be analyzed as a process where both the participants and the researcher contribute to and coproduce the knowledge of the tangible and intangible dimensions of homemaking. The advantage of the presented approach lies in the possibility of linking different social and cultural contexts, and how taking the contribution of researcher(s) and participant(s) into account helps explain both the individual and cultural experiences of different generations of migrants.

"Atmosphere," "spirit," or "flavor" were often the keys to my participants' understanding of the level of settlement in their home in Britain, as well as their level of identification with Russian culture. It was evident that atmosphere was not merely about the quality of objects, but also about the people who invested these objects with meaning. Additionally, with further reading and reflection, I emphasized the role of the researcher in the process of the creation of atmosphere and the way s/he can recognize and decode different characteristics of place as Russian or non-Russian.

The chosen way of conceptualizing the domestic "atmosphere" enables researchers to analyze the interview process as a negotiation of different types of knowledge, which in the end, helps us achieve an understanding of cultural identity and a sense of nation-ness from a different, non-trivial angle. In this way, by reflecting on my own perceptions of homes and objects and combining the researcher's and the migrant's perspective, I aimed to show how the position of the researcher continuously expands and reshapes before, during, and after the study. The interaction with these places reveals the objects' biographies, brings them to life, awakens them, and puts them into a logical sequence for both for the researcher and the participants. These revealed stories of the objects give meanings to experiences, and thus become part of the atmosphere. By visiting these homes, the researcher lives in the space-even if only temporarily-simultaneously with the researched.

\section{Acknowledgements}

An earlier version of this article was presented at the Atmospheres Conference held at the University of Manchester in 2015. I thank my fellow panelists and audience members for their useful questions and suggestions on the article material. I am grateful to A. Salem and to A. Filippov for their insightful comments and support. I also thank the anonymous journal reviewer for extremely helpful feedback. 


\section{References}

Anderson B. (1983) Imagined Communities: Reflections on the Origin and Spread of Nationalism, London: Verso.

Benjamin W. (2008) The Work of Art in the Age of Mechanical Reproduction, London: Penguin.

Bohme G. (1993) Atmosphere as the Fundamental Concept of a New Aesthetics. Thesis Eleven, vol. 36, pp. 113-126.

Blunt A. (2005) Cultural Geography: Cultural Geographies of Home. Progress in Human Geography, vol. 29, no 4, pp. 505-515.

Chevalier S. (1999) The French Two-Home Project: Materialization of Family Identity. At Home: An Anthropology of Domestic Space (ed. I. Cieraad), Syracuse: Syracuse University Press, pp. 83-94.

Filippov A. (2008) Sotsiologiya prostranstva [Sociology of Space], Saint Petersburg: Vladimir Dahl.

Gurova O. (forthcoming) Political Consumerism in Russia after 2011. Cultural Mechanisms of Political Protest in Russia (eds. E. Etkind, B. Beumers, S. Turoma, O. Gurova), London: Routledge.

Hanks P. (ed) (1979) Collins English Dictionary, Sydney: William Collins Sons \& Co.

Heidegger M. (1993) Building-Dwelling-Thinking. Basic Writings (ed. D. F. Krell), London: Routledge, pp. 343-364.

Hurdley R. (2013) Home, Materiality, Memory and Belonging: Keeping Culture, London: Palgrave Macmillan.

Marcoux J.-S. (2001) The Refurbishment of Memory. Home Possessions: Material Culture Behind Closed Doors (ed. D. Miller), Oxford: Berg, pp. 69-86.

Mason J. (1989) Reconstructing the Public and the Private. Home and Family: Creating the Domestic Sphere (eds. G. Allan, G. Crow), Basingstoke: Macmillan, pp. 102-121.

Mehta R., Belk R. W. (1991) Artifacts, Identity, and Transition: Favourite Possessions of Indians and Indian Immigrants to the United States. Journal of Consumer Research, vol. 17 , no 4, pp. 398-411.

Miller D. (2008) Migration, Material Culture and Tragedy: Four Moments in Caribbean Migration. Mobilities, vol. 3, no 3, pp. 397-413.

Miller D. (2010) Stuff, Cambridge: Polity.

Olesen B. B. (2010) Ethnic Objects in Domestic Interiors: Space, Atmosphere and the Making of Home. Home Cultures, vol. 7, no 1, pp. 25-41.

Pahl K. (2012) Every Object Tells a Story. Home Cultures, vol. 9, no 3, pp. 303-327.

Pechurina A. (2011) Russian Dolls, Icons, and Pushkin: Practicing Cultural Identity Through Material Possessions in Immigration. Laboratorium, vol. 3, no 3, pp. 97-117.

Pechurina A. (2014) Positionality and Ethics in the Qualitative Research of Migrants' Homes. Sociological Research Online, vol. 19, no 1. Available at: http://www.socresonline.org.uk/19/1/4.html (accessed 23 May 2016). 
Pechurina A. (2015) Material Cultures, Migrations, and Identities: What the Eye Cannot See, Basingstoke: Palgrave Macmillan.

Pennartz P. J. J. (1986) Atmosphere at Home: A Qualitative Approach. Journal of Environmental Psychology, vol. 6, no 2, pp. 135-153.

Petridou E. (2001) The Taste of Home. Home Possessions: Material Culture Behind Closed Doors (ed. D. Miller), Oxford: Berg, pp. 87-104.

Pink S. (2004) Home Truths: Gender, Domestic Objects and Everyday Life, Oxford: Berg.

Pink S. (2006) The Future of Visual Anthropology: Engaging the Senses, London: Routledge.

Pink S. (2009) Doing Sensory Ethnography, London: Sage.

Pink S. (2012) Domestic Time in the Sensory Home: The Textures and Rhythms of Knowing Practice, Memory and Imagination. Time, Media and Modernity (ed. E. Keightley), London: Palgrave Macmillan, pp. 184-200.

Rapport N., Dawson A. (eds.) (1998) Migrants of Identity: Perceptions of Home in a World of Movement, Oxford: Berg.

Rose G. (2012) Visual Methodologies: An Introduction to Researching with Visual Materials, London: Sage.

Sabonis-Chafee T. (1999) Communism as Kitsch: Soviet symbols in Post-Soviet Society. Consuming Russia: Popular Culture, Sex, and Society since Gorbachev (ed. A. M. Barker), Durham: Duke University Press.

Savas O. (2014) Taste Diaspora: The Aesthetic and Material Practice of Belonging. Journal of Material Culture, vol. 19, no 2, pp. 185-208.

Sigona N., Gamblen A., Liberatore G., Neveu Kringelbach H. (eds.) (2015) Diasporas Reimagined: Spaces, Practices and Belonging, Oxford: University of Oxford.

Smart S. (2011) Ways of Knowing: Crossing Species Boundaries. Methodological Innovation Online, vol. 6, no 3, pp. 27-38.

Svasek M. (ed.) (2012) Moving Subjects, Moving Objects: Migrant Art, Artefacts and Emotional Agency, Oxford: Berghahn.

Tolia-Kelly D. P. (2010) Landscape, Race and Memory: Material Ecologies of Citizenship, London: Routledge.

Woodward S. (2015) Hidden Lives of Dormant Things: Cupboards, Lofts and Shelves. Intimacies: Critical Consumption and Diverse Economies (eds. E. Casey, Y. Taylor), London: Palgrave Macmillan, pp. 216-231. 


\title{
Теоретические и методологические вопросы в изучении и определении русского дома и его атмосферы в контексте миграции
}

\author{
Анна Печурина \\ Преподаватель социологии, Университет Лидс Беккетт \\ Адpec: City Campus, Calverley Building, Room 914, Leeds, LS1 $3 \mathrm{HE}$ \\ E-mail: a.pechurina@leedsbeckett.ac.uk
}

В статье рассматривается связь между материальными и чувственными характеристиками пространства дома на примере исследования домов русских мигрантов в Великобритании, дополненных наблюдениями и саморефлексией автора статьи. В частности, особое внимание уделяется атмосфере дома и вопросу насколько ее определение, создание и поддержание связано с этничностью и культурной идентичностью респондентов/хозяев дома и исследователя, их разделяемыми или отличными представлениями о доме и предметах его символизирующих. Совокупность материальных и чувственных характеристик дома, которые способствуют возникновению так называемого чувства дома определяется в статье как «чувство русскости». Важно отметить, что это чувство может возникнуть не только у хозяев дома, но и у временных гостей, которые интуитивно или осознанно распознают значения предметов и элементов декора как часть русского культурного кода. Ситуация интервью одновременно помогает и ограничивает возможность выявления неочевидных значений и описаний предметов в доме и тем самым вносит двоякий вклад в определение домашней атмосферы. В статье рассматриваются примеры, показывающие связь между материальными и чувственными измерениями культурной идентичности мигрантов и их домов и насколько процессы и практики по поддержанию дома создают особый тип «диаспоральной» атмосферы. Статья следует принципу совмещения различных способов изучения и описания предмета социологического наблюдения, подчеркивая преимущества креативного подхода, при котором чувственные оценки как респондентов, так и наблюдателя являются значимыми. Такая стратегия позволяет достичь более критичную и нетривиальную оценку теоретических концепций и исследовательских ситуаций, описанных в статье.

Ключевые слова: домашнее пространство, атмосфера, материальная культура, миграция, диаспора, русскость 